\title{
Isolation and Evaluation of Ganoderma lucidum from Uttarakhand, India
}

\author{
Shilpi Rawat* \\ Department of Plant Pathology, College of Agriculture, GBPUAT, Pantnagar, India \\ *Corresponding author
}

\section{A B S T R A C T}

\begin{tabular}{|l|}
\hline Ke y w o r d s \\
Ganoderma \\
lucidum, \\
Morphology, \\
Media, \\
Temperature, pH \\
\hline Article Info \\
\hline $\begin{array}{l}\text { Accepted: } \\
\text { 07 February } 2018 \\
\text { Available Online: } \\
\text { 10 March } 2018\end{array}$ \\
\hline
\end{tabular}

\section{Introduction}

Ganoderma lucidum (W.Curt: Fr.) P.Krast is one of the most popular mushrooms in oriental medicine. It is known as "Ling Zhi" in China and "Reishi" or Mannentake in Japan means "Herb of Spiritual potency" (Wagner et al., 2003). In India, it is also called "jarhphorh" while in Haryana, popularly called "Satpatra" and "Hirdo". In India, ethno-medicinal value of Ganoderma lucidum was first reported by Harsh and coworker in 1993. Current world production of G. lucidum is around 6000 tones, half of which comes from China (Verma and Prasad, 2010). World trade in this mushroom is in the range of 1.5 billion US\$, while it is about Rs. 120 crore per annum in India (Geetha et al., 2012). It is one of the most desired medicinal mushroom and has been used for more than 200 years. It is a popular remedy to treat condition like chronic hepatitis, hypertension, cancer, blood pressure, rheumatism, heart problem, paralysis, ulcer, arthristis, tiredness, hepatitis A, B, C, sterility, psoriasis, mumps, epilepsy and alcoholism. Products are available in various forms such as powders, tablet, capsule and syrups. This is probably the first medicinal mushroom to gain importance in India. Ganoderma lucidum has been cultivated by using several different substrates and by maintaining growth parameters such as temperature, relative humidity, water content, air, $\mathrm{pH}$ and light intensity (Changs and Miles, 2004). For this reason, it is very important to evaluate these factors for the optimal mycelial growth of 
Ganoderma lucidum. In this study the mycelial growth of Ganoderma lucidum was observed on different medias as Malt Extract Agar (MEA), Potato Dextrose Agar (PDA), Czapek-Dox Agar (CDA), Sabouraud's Dextrose Yeast Agar (SDYA) and Wheat Extract Agar (WEA) at room temperature $\left(25^{\circ} \mathrm{C}\right)$.

The mycelial growth was observed at temperature ranges viz. $15^{\circ} \mathrm{C}, 20^{\circ} \mathrm{C}, 25^{\circ} \mathrm{C}$, $30^{\circ} \mathrm{C}, 35^{\circ} \mathrm{C}$ and $\mathrm{pH}$ levels viz. 4, 5, 6, 7,8 on MEA media. Present work was undertaken with the objective of evaluation of different factors for the optimal mycelial growth of Ganoderma lucidum and to identify the best isolates.

\section{Materials and Methods}

\section{Collection and isolation of Ganoderma lucidum}

Fruiting bodies of Ganoderma lucidum were collected from the forest areas of Almora (GA), Mukteswar (GM), Dehradun (GD), Pantnagar (GP) and Kashipur (GK) of Uttarakhand during rainy season and isolation of the collected specimens was made using tissue culture technique. The basidiocarps were washed twice with sterilized distilled water and dried with the help of sterilized Whatman filter paper under asepatic condition in the laminar flow inoculation chamber. Bits (3-4 numbers) from internal tissues of basidiocarp were taken with the help of sterilized forceps and were placed on the sterilized Potato Dextrose Agar (PDA) and Malt Extract Agar (MEA) media in the petri plates. Inoculated petri plates with the bits of fungal tissues were incubated at $25 \pm 1^{\circ} \mathrm{C}$ for a week for their growth. The culture tubes were inoculated from full grown fungual culture and incubated at above temperature. The full grown fungal culture tubes were kept in refrigerator for further studies.
Morphological characterization of Ganoderma lucidum isolates

Collected fruiting bodies of Ganoderma lucidum were studied for their morphological characteristics. Macroscopic features such as presence/absence of stripe, color, size and shape of fruiting bodies were recorded. Measurement of basidiospores were carried under compound light microscope using an eyepiece graticule calibrated with a stage micrometer.

Diametric growth of different isolates on different media, temperatures and $\mathbf{p H}$

The experiment was carried out using five different media viz. Malt Extract Agar (MEA), Potato Dextrose Agar (PDA), Czapek-Dox Agar (CDA), Sabouraud's Dextrose Yeast Agar (SDYA) and Wheat Extract Agar (WEA) at room temperature $\left(25^{\circ} \mathrm{C}\right)$. Petri-plates containing $25 \mathrm{ml}$ of the medium were inoculated at the centre with $7 \mathrm{~mm}$ diameter disc of actively growing mycelium of $G$. lucidum isolates under aseptic conditions.

The isolates were inoculated in the petri plate containing $25 \mathrm{ml}$ of MEA media at varying temperature ranges viz. $15^{\circ}, 20^{\circ}, 25^{\circ}, 30^{\circ}$ and $35^{\circ} \mathrm{C}$. The method was same as followed for temperature evaluation but at varying $\mathrm{pH}$ levels viz. 4, 5, 6, 7 and 8 on the MEA medium. $\mathrm{pH}$ was adjusted using concentrated $\mathrm{HCl}$ and concentrated $\mathrm{NaOH}$ solutions for lower and higher $\mathrm{pH}$ values, respectively. In all the experiments each treatments was replicated three times for each isolate and observations were recorded at two days interval upto full growth is observed in any one of the petri plates.

\section{Statistical analysis}

The data was analysed using three factorial $\mathrm{CRD}$ and the difference among mean value 
was tested by using critical differences (CD) values at $5 \%$ level of probability.

\section{Results and Discussion}

Morphological characterization of Ganoderma lucidum isolates.

Isolate GA: Fruiting bodies were large, irregular in shape, copper red in colour, lateral surface appeared glossy, varnished, hard and thick. Basidiospores were ellipsoid, double walled, $6.0-8.9 \mu \mathrm{m} \times 10-12 \mu \mathrm{m}$ in size.

Isolate GM: Fruit bodies were kidney-shaped along with long thick corky, hard stipe of dark brown in color. Fruit bodies were blackish-red in color. Basidiospores were ellipsoid, double walled and size varied between $6.84-7.37 \mu \mathrm{m} \mathrm{x}$ $10.26-11.05 \mu \mathrm{m}$.

Isolate GD: Fruit bodies were irregular with a thin margin and golden brown in colour with shiny appearance. Basidiospores were ellipsoid, cut flat at top, thick walled and 6.24$9.08 \mu \mathrm{m}$ and $9.11-10.00 \mu \mathrm{m}$ in size.

Isolate GP: Fruit bodies were kidney shaped, thick and broader margin. Color of fruit bodies were golden brown at centre, with a cream light yellow margin. Basidiospores ovate, with a rounded base and truncate to narrowly rounded apex, double walled and size in the range of $6.5-8.0 \mu \mathrm{m} \times 10.0-12.0 \mu \mathrm{m}$

Isolate GK: Large fruit bodies with irregular shape and thick, broader margin. Dark black brown fruit bodies with wavy light yellow to cream margin, appearance like a floral pattern, found attached to the base of the tree with a dark thick pileus. Basidiospores were globoid, double walled and size of $7.5 \mu \mathrm{m} \times 11.24 \mu \mathrm{m}$.

The basidiocarp and basidiospore morphology has also been studied by Pegler and Young (1973) and Adaskaveg and Gilbertson (1986).
Diametric growth of different isolates on different media, temperatures and $\mathrm{pH}$

Among the media tested MEA exhibit maximum average mycelial growth $(7.64 \mathrm{~cm})$ followed by PDA $(5.64 \mathrm{~cm})$, SDYA $(3.46 \mathrm{~cm})$, WEA $(2.92 \mathrm{~cm})$ and least in CDA $(2.34 \mathrm{~cm})$ on $8^{\text {th }}$ day of observation by all the isolate and differ significantly with each other. On MEA isolate GA showed maximum (full growth) diametric growth of mycelium $(9.0 \mathrm{~cm})$ and different significantly from other isolates. Next to this, isolates GP gave mycelial growth of $7.73 \mathrm{~cm}$ on $8^{\text {th }}$ day and found to be at par with isolate GD $(7.66 \mathrm{~cm})$ and differ significantly with other isolates. Lowest mycelial growth $(6.50 \mathrm{~cm})$ was exhibited by GK followed by $\mathrm{GM}(7.30 \mathrm{~cm})$ on $8^{\text {th }}$ day observation. However, on PDA average highest mycelial growth $(6.90 \mathrm{~cm})$ was recorded in isolate GA which was at par with GP showing mycelial growth of $6.83 \mathrm{~cm}$ and found significantly superior than other isolates. The next isolate was GD $(5.16 \mathrm{~cm})$ followed by $\mathrm{GK}(4.90 \mathrm{~cm})$ and minimum mycelial growth was recorded in isolate GM $(4.40 \mathrm{~cm})$ which differs significantly from others (Table 1-3).

On CDA medium isolate GA here also exhibited maximum mycelial growth of $2.83 \mathrm{~cm}$ on $8^{\text {th }}$ day and found to be at par with GP $(2.76 \mathrm{~cm})$. Other isolates also exhibited significant variation to each other giving diametric growth range from $1.86 \mathrm{~cm}$ to $2.23 \mathrm{~cm}$. On SDYA, isolate GA gave mycelial growth of $4.66 \mathrm{~cm}$ which was found significantly superior to all other isolates. Isolate GP gave mycelial growth of $3.90 \mathrm{~cm}$ which differs significantly with isolates GK $(3.13 \mathrm{~cm})$, GD $(2.90 \mathrm{~cm})$ and $\mathrm{GM}(2.70 \mathrm{~cm})$ which exhibited slow growth rate. On WEA isolate GA here also exhibited maximum mycelial growth of $3.46 \mathrm{~cm}$ on $8^{\text {th }}$ day which was at par with isolate GP $(3.33 \mathrm{~cm})$ and differ significantly from other isolates. 
Table.1 Diametric growth of Ganoderma lucidum (in $\mathrm{cm}$ ) isolates on different media

\begin{tabular}{|c|c|c|c|c|c|c|c|c|c|c|c|c|c|c|c|c|c|c|c|c|c|c|c|c|}
\hline \multirow[b]{2}{*}{ Media } & \multicolumn{5}{|c|}{$2^{\text {nd }}$ days } & \multirow[t]{2}{*}{ Mean } & \multicolumn{5}{|c|}{$4^{\text {th }}$ days } & \multirow[t]{2}{*}{ Mean } & \multicolumn{5}{|c|}{$6^{\text {th }}$ days } & \multirow[t]{2}{*}{ Mean } & \multicolumn{5}{|c|}{$8^{\text {th }}$ days } & \multirow[t]{2}{*}{ Mean } \\
\hline & GA & GM & GK & GP & GD & & GA & GM & GK & GP & GD & & GA & GM & GK & GP & GD & & GA & GM & GK & GP & GD & \\
\hline MEA & 3.50 & 1.00 & 0.08 & 2.16 & 1.36 & 1.76 & 5.70 & 2.50 & 3.00 & 3.08 & 2.66 & 3.53 & 7.20 & 4.04 & 4.8 & 6.23 & 4.80 & 5.48 & 9.00 & 7.30 & 6.50 & 7.73 & 7.66 & 7.64 \\
\hline PDA & 2.16 & 0.00 & 1.00 & 1.56 & 1.00 & 1.14 & 3.73 & 1.26 & 2.30 & 2.96 & 2.33 & 2.52 & 5.73 & 3.06 & 3.50 & 5.50 & 3.86 & 4.33 & 6.90 & 4.40 & 4.90 & 6.83 & 5.16 & 5.64 \\
\hline SDYA & 2.03 & 0.00 & 0.00 & 0.86 & 0.00 & 0.58 & 2.70 & 0.00 & 0.90 & 1.90 & 0.86 & 1.27 & 3.70 & 1.40 & 2.03 & 2.83 & 1.73 & 2.34 & 4.66 & 2.70 & 3.13 & 3.90 & 2.90 & 3.46 \\
\hline WEA & 1.60 & 0.00 & 0.73 & 0.86 & 0.53 & 0.76 & 1.96 & 0.66 & 1.66 & 1.66 & 1.06 & 1.40 & 2.90 & 1.8 & 2.4 & 2.8 & 1.8 & 2.36 & 3.4 & 2.40 & 3.03 & 3.33 & 2.40 & 2.92 \\
\hline Mean & 1.97 & 0.20 & 0.50 & 1.09 & 0.58 & & 3.06 & 0.88 & 1.72 & 2.28 & 1.55 & & 4.36 & 2.30 & 2.79 & 3.85 & 2.74 & & 5.37 & 3.73 & 3.92 & 4.91 & 4.07 & \\
\hline \multicolumn{25}{|c|}{ CD at $5 \%$ Media $\times$ Isolates 0.07} \\
\hline \multicolumn{25}{|c|}{ Media $\times$ days 0.68} \\
\hline \multicolumn{25}{|c|}{ Isolates $\times$ days $\mathbf{0 . 6 8}$} \\
\hline Media & sol & $\times 1$ & 0.18 & & & & & & & & & & & & & & & & & & & & & \\
\hline
\end{tabular}

Table.2 Diametric growth of Ganoderma lucidum (in $\mathrm{cm}$ ) isolates on different temperature

\begin{tabular}{|c|c|c|c|c|c|c|c|c|c|c|c|c|c|c|c|c|c|c|c|c|c|c|c|c|}
\hline \multirow[b]{2}{*}{ Temperate } & \multicolumn{5}{|c|}{$2^{\text {nd }}$ days } & \multirow[t]{2}{*}{ Mean } & \multicolumn{5}{|c|}{$4^{\text {th }}$ days } & \multirow[t]{2}{*}{ Mean } & \multicolumn{5}{|c|}{$6^{\text {th }}$ days } & \multirow[t]{2}{*}{ Mean } & \multicolumn{5}{|c|}{$8^{\text {th }}$ days } & \multirow[t]{2}{*}{ Mean } \\
\hline & GA & GM & GK & GP & GD & & GA & GM & GK & GP & GD & & GA & GM & GK & GP & GD & & GA & GM & GK & GP & GD & \\
\hline $15^{\circ} \mathrm{C}$ & 1.36 & 0.89 & 1.10 & 1.43 & 0.43 & 1.04 & 2.53 & 2.33 & 2.33 & 2.43 & 1.73 & 2.28 & 3.76 & 3.66 & 3.73 & 3.40 & 2.96 & 3.50 & 5.63 & 4.93 & 5.10 & 4.76 & 4.50 & 4.98 \\
\hline $20^{\circ} \mathrm{C}$ & 2.20 & 0.63 & 0.89 & 2.03 & 1.46 & 1.46 & 3.13 & 2.16 & 2.16 & 3.66 & 2.90 & 2.80 & 5.53 & 4.20 & 5.40 & 5.53 & 4.93 & 5.12 & 8.23 & 6.56 & 7.16 & 7.70 & 7.06 & 7.34 \\
\hline $25^{\circ} \mathrm{C}$ & 2.53 & 1.00 & 1.30 & 1.40 & 1.40 & 1.52 & 3.73 & 3.46 & 4.26 & 3.73 & 3.40 & 3.72 & 6.26 & 5.26 & 6.63 & 6.80 & 6.33 & 6.26 & 9.00 & 8.23 & 9.00 & 8.83 & 8.53 & 8.72 \\
\hline $30^{\circ} \mathrm{C}$ & 0.30 & 0.00 & 0.00 & 0.96 & 0.23 & 0.30 & 2.13 & 0.70 & 0.86 & 2.46 & 1.63 & 1.56 & 3.53 & 2.36 & 2.56 & 3.76 & 2.86 & 3.02 & 4.80 & 3.80 & 4.36 & 5.10 & 4.16 & 4.44 \\
\hline $35^{\circ} \mathrm{C}$ & 0.36 & 0.00 & 0.00 & 0.70 & 0.33 & 0.28 & 1.80 & 0.33 & 0.43 & 1.56 & 1.73 & 1.17 & 2.96 & 1.83 & 1.80 & 2.96 & 2.46 & 2.40 & 4.23 & 3.00 & 3.26 & 3.93 & 3.46 & 3.58 \\
\hline Mean & 1.35 & 0.56 & 0.66 & 1.30 & 0.77 & & 2.66 & 1.80 & 2.01 & 2.77 & 2.28 & & 4.41 & 3.46 & 4.02 & 4.49 & 3.91 & & 6.38 & 5.30 & 5.78 & 6.06 & 5.54 & \\
\hline \multicolumn{25}{|c|}{ CD at $5 \%$ Temperature $\times$ Isolates 0.09} \\
\hline \multicolumn{25}{|c|}{ Temperature $\times$ days 0.08} \\
\hline \multicolumn{25}{|c|}{ Isolates $\times$ days $\mathbf{0 . 0 8}$} \\
\hline \multicolumn{25}{|c|}{ Temperature $\times$ Isolates $\times$ days 0.19} \\
\hline
\end{tabular}


Table.3 Diametric growth of G. lucidum (in $\mathrm{cm}$ ) isolates on different $\mathrm{pH}$ at temperature $25^{\circ} \mathrm{C}$

\begin{tabular}{|c|c|c|c|c|c|c|c|c|c|c|c|c|c|c|c|c|c|c|c|c|c|c|c|c|}
\hline & \multicolumn{5}{|c|}{$2^{\text {nd }}$ days } & \multirow[t]{2}{*}{ Mean } & \multicolumn{5}{|c|}{$4^{\text {th }}$ days } & \multirow[t]{2}{*}{ Mean } & \multicolumn{5}{|c|}{$6^{\text {th }}$ days } & \multirow[t]{2}{*}{ Mean } & \multicolumn{5}{|c|}{$8^{\text {th }}$ days } & \multirow[t]{2}{*}{ Mean } \\
\hline pH & GA & GM & GK & GP & GD & & GA & GM & GK & GP & GD & & GA & GM & GK & GP & GD & & GA & GM & GK & GP & GD & \\
\hline 4.0 & 1.40 & 0.7 & 1.36 & 1.70 & 1.06 & 1.24 & 2.23 & 1.23 & 2.33 & 2.90 & 2.83 & 2.30 & 4.63 & 2.96 & 3.90 & 4.40 & 3.90 & 3.96 & 6.23 & 4.23 & 5.50 & 5.70 & 5.43 & 5.42 \\
\hline 5.0 & 1.33 & 1.56 & 1.80 & 2.23 & 2.00 & 1.78 & 3.16 & 2.66 & 2.73 & 4.46 & 3.60 & 3.32 & 5.86 & 4.56 & 4.46 & 6.90 & 4.93 & 5.34 & 8.16 & 6.03 & 6.63 & 8.83 & 7.60 & 7.45 \\
\hline 6.0 & 1.33 & 1.06 & 1.40 & 2.30 & 1.83 & 1.58 & 3.53 & 2.36 & 3.46 & 4.13 & 4.10 & 3.52 & 6.53 & 4.13 & 5.43 & 7.13 & 6.90 & 6.02 & 8.23 & 6.63 & 6.90 & 8.83 & 8.16 & 7.75 \\
\hline 7.0 & 1.53 & 1.30 & 1.70 & 1.90 & 1.86 & 1.66 & 2.60 & 2.53 & 3.13 & 3.86 & 3.60 & 3.14 & 5.03 & 4.03 & 3.83 & 5.20 & 5.40 & 4.70 & 5.86 & 5.46 & 5.23 & 6.23 & 6.13 & 5.78 \\
\hline 8.0 & 1.06 & 0.36 & 1.30 & 1.36 & 1.23 & 1.06 & 1.96 & 1.46 & 1.76 & 2.06 & 2.30 & 1.91 & 3.13 & 2.53 & 2.70 & 3.26 & 3.43 & 3.01 & 4.63 & 3.70 & 3.80 & 4.36 & 4.46 & 4.19 \\
\hline Mean & 1.33 & 0.99 & 1.51 & 1.90 & 1.60 & & 2.70 & 2.05 & 2.68 & 3.48 & 3.24 & & 5.04 & 3.64 & 4.06 & 5.38 & 4.91 & & 6.62 & 5.21 & 5.61 & 6.79 & 6.36 & \\
\hline \multicolumn{25}{|c|}{ CD at $5 \% \mathrm{pH} \times$ Isolates 0.33} \\
\hline \multicolumn{25}{|c|}{$\mathrm{pH} \times$ days 0.30} \\
\hline \multicolumn{25}{|c|}{ Isolates $\times$ days $\mathbf{0 . 3 0}$} \\
\hline $\mathrm{pH} \times \mathbf{I}$ & ate & lav & & & & & & & & & & & & & & & & & & & & & & \\
\hline
\end{tabular}

Table.4 Means for main effects

\begin{tabular}{|c|c|c|c|c|c|}
\hline Media & Mean & Temperature & Mean & $\mathrm{pH}$ & Mean \\
\hline MEA & 4.60 & $15^{\circ} \mathrm{C}$ & 2.95 & 4.0 & 3.23 \\
\hline PDA & 3.41 & $20^{\circ} \mathrm{C}$ & 4.18 & 5.0 & 4.47 \\
\hline CDA & 1.19 & $25^{\circ} \mathrm{C}$ & 5.05 & 6.0 & 4.72 \\
\hline SDYA & 1.91 & $30^{\circ} \mathrm{C}$ & 2.33 & 7.0 & 3.82 \\
\hline WEA & 1.85 & $35^{\circ} \mathrm{C}$ & 1.86 & 8.0 & 2.54 \\
\hline CD at $5 \%$ & 0.03 & CD at $5 \%$ & 0.04 & CD at $5 \%$ & 0.05 \\
\hline GA & 3.69 & GA & 3.70 & GA & 4.03 \\
\hline$\overline{\text { GM }}$ & 1.78 & GM & 2.76 & GM & 2.97 \\
\hline GK & 2.23 & GK & 3.12 & GK & 3.47 \\
\hline GP & 3.03 & GP & 3.66 & GP & 4.38 \\
\hline GD & 2.23 & GD & 3.12 & GD & 3.92 \\
\hline CD at $5 \%$ & 0.03 & CD at $5 \%$ & 0.04 & CD at $5 \%$ & 0.05 \\
\hline D2 & 0.87 & D2 & 0.91 & D2 & 1.46 \\
\hline D4 & 1.90 & D4 & 2.30 & D4 & 2.84 \\
\hline D6 & 3.21 & D6 & 4.06 & D6 & 4.60 \\
\hline D8 & 4.40 & D8 & 5.81 & D8 & 6.12 \\
\hline CD at $5 \%$ & 0.03 & CD at $5 \%$ & 0.38 & CD at $5 \%$ & 0.04 \\
\hline
\end{tabular}


Isolates GK showed mycelial growth of $3.03 \mathrm{~cm}$ and exhibited significant variation to other isolates. Isolates GD and GM each showed minimum growth of $2.34 \mathrm{~cm}$ only.

All the five isolates of G. lucidum grew well on Malt Extract Agar followed by Potato Dextrose Agar and isolate GA with mycelial growth of $5.37 \mathrm{~cm}$ was found to be superior followed by isolate GP $(4.91 \mathrm{~cm})$ on $8^{\text {th }}$ day observation.

MEA with mycelial growth of $4.60 \mathrm{~cm}$ on $8^{\text {th }}$ day $(4.40 \mathrm{~cm})$ was found to be best for isolate GA $(3.69 \mathrm{~cm})$. Malt Extract Agar (MEA) has been reported as the most suitable medium for the growth of G. lucidum by Adaskaveg and Gilbertson (1986), Shukla and Uniyal (1989), Khara et al., (1997) and Mishra (2010).

Among the temperatures, all the isolates showed average maximum mycelial growth at $25^{\circ} \mathrm{C}(8.72 \mathrm{~cm})$ followed by $20^{\circ} \mathrm{C}(7.34 \mathrm{~cm})$ and minimum at $35^{\circ} \mathrm{C}(3.58 \mathrm{~cm})$ on $8^{\text {th }}$ day observation. At $25^{\circ} \mathrm{C}$ temperature on $8^{\text {th }}$ day, isolates $\mathrm{GA}$ and $\mathrm{GK}$ exhibited maximum mycelial growth $(9.0 \mathrm{~cm}$ each). Isolates GP $(8.83 \mathrm{~cm})$ and GD $(8.53 \mathrm{~cm})$ were at par to each other but differs significantly with isolated GM $(8.23 \mathrm{~cm})$ which exhibited lowest mycelial growth on $8^{\text {th }}$ day. However, at temperature $20^{\circ} \mathrm{C}$ highest average mycelial growth $(8.23 \mathrm{~cm})$ was recorded from isolate GA which was found significantly superior than other isolates. The next isolate in order to superiority was GP giving $7.70 \mathrm{~cm}$ mycelial growth followed by isolate GD $(7.16 \mathrm{~cm})$ and GK $(7.06 \mathrm{~cm})$ which were at par to each other. Here also, isolates GM produces minimum growth $(6.56 \mathrm{~cm})$ only. At $15^{\circ} \mathrm{C}$ temperature, isolates GA gave average mycelial growth of $5.63 \mathrm{~cm}$ and found superior to all other isolate. Isolates GK gave mycelial growth of $5.10 \mathrm{~cm}$ which differs significantly with all others. Other isolates GP $(4.76 \mathrm{~cm})$, GD $(4.50 \mathrm{~cm})$ and GM $(4.93 \mathrm{~cm})$ exhibited minimum growth on $8^{\text {th }}$ day observations. At $30^{\circ} \mathrm{C}$, isolate GP exhibited highest mycelial growth $(5.10 \mathrm{~cm})$ on $8^{\text {th }}$ day observation and differ significantly from other isolates followed by isolate GA showed $4.80 \mathrm{~cm}$ mycelial growth. Other isolates also exhibited significantly variation to each other giving diametric mycelial growth ranges from $3.80 \mathrm{~cm}-4.36 \mathrm{~cm}$. Minimum growth of all the isolates were recorded at $35^{\circ} \mathrm{C}$ temperature on which highest mycelial diametric growth $(4.23 \mathrm{~cm})$ obtained from isolate GA with followed by isolate GP $(3.93 \mathrm{~cm})$. Minimum growth $3.0 \mathrm{~cm}$ and $3.26 \mathrm{~cm}$ were recorded from isolated GM and GD, respectively. All the isolates varies significantly to each other. Increasing the temperature $35^{\circ} \mathrm{C}$ or above it, resulted into decrease in average growth rate.

Temperature range of $20^{\circ} \mathrm{C}-25^{\circ} \mathrm{C}$ was found to best for isolate GA with mycelial growth of $6.38 \mathrm{~cm}$ followed by isolate GP $(6.06 \mathrm{~cm})$ on $8^{\text {th }}$ day observation. Optimal mycelial growth $(5.05 \mathrm{~cm})$ was exhibited at temperature of $25^{\circ} \mathrm{C}$ on $8^{\text {th }}$ day $(5.81 \mathrm{~cm})$ where isolate GA gave maximum mycelial growth of $3.70 \mathrm{~cm}$ (Table 4). The optimum temperature of $20^{\circ} \mathrm{C}$ $25^{\circ} \mathrm{C}$ has been reported to give maximum mycelial growth by Song et al., (2007) and Nasreen et al., (2005).

For the $\mathrm{pH}$ study, data showed that all the isolates exihibited maximum mycelial growth $(7.75 \mathrm{~cm})$ at $\mathrm{pH} 6.0$ followed by $\mathrm{pH} 5.0$ $(7.45 \mathrm{~cm})$ and least mycelial growth $(4.19 \mathrm{~cm})$ at $\mathrm{pH} 8.0$ by all the isolates on $8^{\text {th }}$ day of observation and differ significantly with each other. At pH 6.0, isolates GP gave maximum mycelial growth $(8.83 \mathrm{~cm})$ and differs significantly from all other isolates. Mycelial growth by isolate GA $(8.23 \mathrm{~cm})$ and GD $(8.16 \mathrm{~cm})$ were at par to each other but differs significantly with all other isolates. Minimum growth of $6.63 \mathrm{~cm}$ was exhibited by isolate GM. At pH 5.0 also, isolate GP gave maximum diametric mycelial growth 
$(8.83 \mathrm{~cm})$ and differs significantly with all other isolates. Isolate GA was found next to isolate GP with $8.16 \mathrm{~cm}$ of diametric mycelial growth and differs significantly with all other isolates. Minimum growth of mycelium $6.03 \mathrm{~cm}$ per was recorded in isolate GM. At $\mathrm{pH}$ 7.0, the isolate GP showed diametric mycelial growth of $6.23 \mathrm{~cm}$ on $8^{\text {th }}$ day observation, which was at par with isolate GD $(6.13 \mathrm{~cm})$ but differs significantly from other isolates. Isolates GA and GM resulted in diametric mycelial growth of $5.86 \mathrm{~cm}$ and $5.46 \mathrm{~cm}$ and minimum diametric mycelial growth of $5.23 \mathrm{~cm}$ was exhibited by isolate GK on $8^{\text {th }}$ day. At $\mathrm{pH} 8.0$ on $8^{\text {th }}$ day, isolates GA and GD were at par to each other with $4.63 \mathrm{~cm}$ and $4.64 \mathrm{~cm}$ of diametric mycelial growth but differs significantly to other isolates.

Isolates GP, GK and GM showed diametric mycelial growth of $4.36 \mathrm{~cm}, 3.80 \mathrm{~cm}$ and $3.70 \mathrm{~cm}$, respectively. At $\mathrm{pH} 4.0$ on $8^{\text {th }}$ day, isolate GA exhibited diametric mycelial growth of $6.23 \mathrm{~cm}$ which differs significantly from all other isolates. Isolates GP, GD, and GK exhibited diametric mycelial growth in the range of $5.43 \mathrm{~cm}$ to $5.70 \mathrm{~cm}$ and were at par to each other. Minimum average mycelial growth of $4.23 \mathrm{~cm}$ was exhibited by isolate GM.

All the isolates preferred acidic $\mathrm{pH}$ 5.0-6.0 for their growth. Isolate GP was found to be superior with maximum mycelia growth $(6.79 \mathrm{~cm})$ followed by isolate GA $(6.62 \mathrm{~cm})$. $\mathrm{pH}$ of $6.0(4.72 \mathrm{~cm}$ mycelial growth) was superior for all the isolates and isolate GP $(4.72 \mathrm{~cm})$ on $8^{\text {th }}$ day $(6.12 \mathrm{~cm})$ gave maximum mycelial growth. It has also been reported that Ganoderma lucidum preferred acidic $\mathrm{pH}$ by Venkatarayan (1935), Triratana et al., (1991), Khara et al., (1997) and Rai (2003). pH 5 is found most suitable for the mycelial growth of Ganoderma lucidum by Mishra (2010) and Nasreen et al., (2005).
Based on the present study it can be concluded that different ganoderma isolates favours malt extract agar media with a temperature of $20^{\circ} \mathrm{C}-25^{\circ} \mathrm{C}$ and $\mathrm{pH}$ of 5.0- 6.0 for the optimal mycelial growth and among the five different isolates, isolate GA and isolate GP was found to be superior on $8^{\text {th }}$ day observations.

\section{Acknowledgements}

Author is thankful to Mushroom Research and Training Centre, Pantnagar for providing the facility to conduct the study.

\section{References}

Adaskaveg JE, Gilbertson RL 1986. Cultural studies and genetics of sexuality of Ganoderma lucidum and $G$. tsugae in relation to the taxonomy of the $G$. lucidum complex. Mycologia 78: 694704.

Chang ST, Miles PG 2004. Mushrooms: Cultivation, nutritional value, medicinal effect and environmental impact. $\left(2^{\text {nd }}\right.$ edition) Boca Raton, CRC Press.

Geetha D, Suharban M, Gokulapalan, Rani CVD 2012. A low cost technology for cultivation of Ganoderma lucidum. Mushroom Research 21(1): 49-53.

Harsh NSK, Rai BK, Tiwari DP 1993. Use of Ganoderma lucidum in folk medicine. Indian Journal of Tropical Biodiversity 1(4):324-326.

Khara HS, Singh Jatinder 1997. Diagnosis of G. lucidum root rot of trees, the cultural characteristics, spore germination and percentage of root-decay. Plant Disease Research 12(2): 108-112.

Mishra KK, Singh RP 2010. Cultural and biochemical variability amongst indigenous Ganoderma lucidum isolates from Uttarakhand. Mushroom Research 19: 74-81. 
Nasreen Z, Kausar T, Nadeem M, Bajwa R 2005. Study of different growth parameters in Ganoderma lucidum. Mycologia Aplicada International 17 (1): 5-8.

Pegler DN, TWK Young 1973. Basidiospiores form in the british species of Ganoderma Karst. Kew Bull 28:351-369

Rai RD 2003. Successful cultivation of the medicinal mushroom Reishi (Ganoderma lucidum) in India. Mushroom Research 12(2):87-91.

Shukla AN, Uniyal K 1989. Antagonistic interactions of Ganoderma lucidum (Leyss.) against some soil microorganisms. Current Science 58(5):265267.

Song M, Kim N, Lees, Hwang S 2007. Use of Whey permeate for cultivating ganoderma lucidum mycelia. Journal of Dairy Science 90:2141-2146.

Triratana S, Jhaithatgoon S, Gawgla M 1991.Cultivation of G. lucidum in sawdust bags. Science and cultivation of edible fungi, Maher (ed) Balkema, Rotterdam 567-572.

Venkatarayan SV 1935. The biology of $G$. lucidum on areca and coconut palms. Phytopathology 26: 153-175.

Verma A, Prasad R 2010. Induced single spore germination in Ganoderma lucidum. Mushroom Research 19 (2):68-73.

Wagner R, Mitchell DA, Sassaki GL, Amazonas MAL deA, Berovic M 2003. Current technique for the cultivation of Ganoderma lucidum for the production of biomass, ganoderic acid and polysaccharides. Food Technology and Biotechnology 41(4): 371-382.

\section{How to cite this article:}

Shilpi Rawat. 2018. Isolation and Evaluation of Ganoderma lucidum from Uttarakhand. Int.J.Curr.Microbiol.App.Sci. 7(03): 472-479. doi: https://doi.org/10.20546/ijcmas.2018.703.057 